\title{
The Effect of Teaching Critical Thinking on Al-Buraimi University College students' Writing Skills: A Case Study
}

\author{
Yahia Ashour Mohammed AlKhoudary \\ Al Buraimi University College, Al Buraimi, the Sultanate of Oman \\ E-mail: alkhoudary@buc.edu.om
}

Received: 20-04- 2015

Published: 01-11- 2015
Accepted: 25-07- 2015

Advance Access Published: August 2015

doi:10.7575/aiac.ijalel.v.4n.6p.212 URL: http://dx.doi.org/10.7575/aiac.ijalel.v.4n.6p.212

\begin{abstract}
This study explores the role of writing in developing students' critical thinking. It also sheds light on traditional writing assignments which fail to help students develop their comprehension of course content and evaluate their writing products critically. Moreover, this probe is to discover learners and teachers' attitude towards the role of critical thinking in promoting the writing skills at AlBuraimi University College (BUC). The result of this study focuses on the effect of integrating critical thinking on learners' performance. The procedure of this investigation is based on a combination of qualitative, quantitative (1) one hundred students who are taking writing course are selected randomly and divided into two groups; (2) pre- and posttests conducted to both groups; (3) twenty teachers were selected randomly (10 males and 10 females); questionnaires are administered to EFL teachers at BUC. The findings of this study illustrate that students who write critically are mostly motivated and their performance is affected positively. It also reveals that there are significant differences in posttest scores between treatment and controlled group. Moreover, teachers' response to questionnaire supports the idea of integrating critical thinking in teaching the writing skills at BUC. Thus, is recommended that teachers should use thinking skills to enhance students' writing performance and creativity.
\end{abstract}

Keywords: Critical Thinking, Process Writing Approach, signal words, teaching techniques

\section{Introduction}

Integrating critical thinking (CT, hereafter) in the EFL/ESL classroom is a controversial issue all educators and course designers are concerned about. Many teachers lack the skill of teaching CT in the classroom. The idea of this paper emerges from my experience in teaching the writing skills that requires students to go through some stages before producing the final product. Moreover, the courses and curriculum in The Sultanate of Oman need updating to fix the competence of learners who have not been trained to be critical thinkers.

The ultimate goal of using CT is to increase students' awareness of the importance of participating and involving in writing assignment that encourages learners to accept or refute information they receive. So, asking questions during the lesson enhances learners' thoughts. Students at BUC who are taught writing through process writing approach (PWA) produced well-organized and logical products. CT skills can enhance students' writing performance if students are welltrained in using signal words in reorganizing their brainstormed ideas. This paper will investigate the importance of incorporating CT in teaching the writing skills and its effect on BUC students' performance.

The findings show that $\mathrm{CT}$ is the best remedy to empower the students' writing skill and all relevant difficulties. They also show that BUC students and teachers can fully rely on teaching CT in producing neat piece of writing. CT encourages language learners to monitor their progress, increase both learners and teachers' motivation and ameliorate students' behavior in the writing classroom. CT is also an ongoing process, which takes time, patience to support learners to have active learning. Moreover, thinking skills may not be taught in isolation but it may be linked to teaching writing since such a skill is an intellectual.

\subsection{Background and significance of the study}

The idea of teaching CT at BUC writing classroom arises from the researcher's observation in teaching EFL during teaching EFL learners in different levels. It is observed that CT is neglected in the EFL classroom particularly in the writing classrooms. In an interview with professor Sadick (2014) who currently teaches literature in the United Arab Emirates University, declares that his students are unable to write a critical paper about novels' characters. As a result, most classrooms and curriculum lack to incorporate CT to train students how to citizen charterers and instigate the schema and former experience. Despite the spread of technological aids and encouragement of the Ministry of Higher Education in The Sultanate of Oman, the traditional teachers are still available at colleges and universities. The result is rote-learning and short-long learning since students are receiver of information because of the method of teaching some teachers use. This study is significant to both teachers and course designers to insert CT in teaching the writing skills 
since it is new to EFL teachers at BUC whose teachers use lecturing method ignoring the core of training learners' minds to exploit their previous experience in facilitating materials that promote their thinking skills. EFL teachers are also lack of learning how to teach $\mathrm{CT}$ in their classrooms and change their perspectives towards improving students' writing performance.

\subsection{The purpose of the study}

The purpose of this study is to investigate the effect of the writing skills in developing students' CT and to study the feasibility of introducing the new system to EFL teachers and learners in Oman, and promote new researches in the area of integrating CT in EFL/ESL classroom in Oman.

Thus, the objectives of this study are as follows:

1. To examine the manifold of relationship between theory and practice in teaching CT using Process writing at BUC.

2. To check the applicability of using CT in teaching writing courses.

3. To promote new researches in the area of teaching $\mathrm{CT}$ in other courses.

\subsection{Research Questions}

There are two questions, divided into four sub-questions:

(1) a. Are there any differences between students' performance who drafts, redraft and edits their writing and those who do not at BUC?

b- Do BUC students who are exposed to CT improve their writing performance?

(2) a. To what extent do EFL/ESL teachers integrate CT in the writing classes at BUC?

b- What are the factors that affect on using CT in teaching the writing skills at BUC?

\subsection{Hypotheses}

The following hypotheses will be tested in this study:

1. Students who revise their drafts have positive attitude towards CT.

2. Teachers who use CT in teaching the writing skills affects students' performance.

\subsection{Rationale}

CT in teaching the writing skills is the central of active learning since students are interact with the text they are writing using their previous knowledge. Also, to my best knowledge, teachers carry out their teaching activities focusing on contents only at BUC. Moreover, teaching and learning activities are confined to knowledge and comprehension only. CT skills are skills that children and adults need to interact with academic situations. Therefore, EFL teachers should work hard to integrate CT in their classroom since it affects on learners' performance positively.

\section{Literature Review}

Incorporating $\mathrm{CT}$ in teaching the writing skills has become a required technique to overwhelm all activities and tasks in the classroom. Moreover, CT can be employed in teaching the four skills. For example, writing, reading and speaking those curriculum designers can integrate $\mathrm{CT}$ in the courses.

\subsection{What is critical thinking?}

Hashmi (2012) defines CT as creative skills to produce new ideas and solve problems through reasoning, interpret symbolic data and develop learning ways for active learning. CT is applicable in all classrooms regardless of socioeconomic standard of the learners. Pither \& Sodden (2000) state that learners will be motivated when brainstorm related ideas to the targeted topic. Johnson et al. (2000) states that CT is the result of cooperative learning strategy promote intellectual dialogic, persuasive and critical analysis. Johnson \& Johnson (1995) indicate that debating and understanding different perspectives and willingness to change their mentality towards using CT in writing. Corttell (2005) defines CT as an exercise of the mind since it has a fundamental previous knowledge that can be a systematized way of thinking. Paul (1985) defines CT as "learning how to ask and answer questions, synthesis and assessment those ideas" (p. 37).

Likewise, Brookfield (1987) maintains that CT includes two interrelated processes: "identifying and challenging assumptions, and imagining and exploring others" (229). Pitcher and Soden (2000) concur that CT encompasses a number of abilities such as identifying a problem and the assumptions on which it is based, focusing the problem, analyzing, understanding and making use of inference. $\mathrm{Ku}(2009)$ maintains the maturation of consideration of $\mathrm{CT}$ from a preoccupation with understating to a cognitive aspect. A critical thinker must have a strong intention to believe in the importance of good thinking so as to look for better outcome (71).

From my experience in teaching the writing skills in EFL classroom in Oman at BUC in particular, students ask questions, collect and assess information to come out with logical and organized writing product. Students who are not 
given enough opportunity to involve in writing essays, come out with rote-learning and do not have the ability to produce a well- organized essay since they are not trained in using signal words to refute or accept the ideas related to the topic. Pithers \& Soden (2000) point out that a cognitive ability connected with a variety of skills such as comprehending, recognizing, and intellectualize a topic.

\subsection{Integrating Thinking in the Writing Classroom}

Traditional EFL teachers consider the first draft as the final focusing on grammatical and spelling errors regardless of the logical and organized text. Bean (1996) explains that there is a relationship between writing and critical thinking that focuses on solving problems. Consequently, he says, "presenting students with problems, then, taps into something natural and self-fulfilling in our beings" (3). Bean encourages curriculum designers to include critical thinking goals. Kurfiss (1988) points out that "students are active, involved, consulting and arguing with each other, and responsible for their own learning" (quoted in Bean .5). Bean explains that writing assignments have flexibility to integrate CT tasks into writing courses because the writing process involves CT (5). He suggests that EFl/ESL teachers need to design CT tasks to engage students in doing writing tasks in groups to generate and discuss ideas and organized logically. Bean indicate that using writing to promote deep learning is not the amount of writing in a course, but the quality of the writing assignments (13). Bean suggests strategies for designing CT tasks to build bridges between students' prior knowledge and the new materials.

Cole (2008) and Mirzaii (2012) maintain that the power of essay question stimulates syntactic thinking that student brainstorm all the ideas from their previous experience. The problem with traditional writing class is that it leads to a view of writing as a set of isolated skills unconnected to an authentic desire to converse with interested readers about their ideas. From my experience in teaching the writing skill, formal academic writing requires analytical or argumentative thinking and is characterized by a logical structure. I think that the learners who think perfectly excel at writing logical and well-organized essays requiring analysis.

Students learn thinking in gathering ideas and synthesizing compositions since CT is to increase students' thinking skill competence that encourages student-writers to accept or refute the ideas they are writing about to persuade their readers that they have their own opinions and they can make decisions during selecting the most related ideas to the topic they are writing about and paraphrasing when writing research drafts. As a result, they are learning what and how to analyze, evaluate and use their former experiences in promoting their writing skills.

Writing instigates students to discover, develop and modify ideas since the messy jotted information requires students to follow the PW that includes many stages to produce a neat one after working hard to clarify meanings without worrying about clarify for their audiences. In the writing classroom, students who are trained in using PW reshape their original drafts thinking about their readers. Macknight (2000) argues that teaching CT is an essential technique to promote learning and teaching. During teaching the writing skills, it is found out that students who are involved in group discussion enhance their CT.

\subsection{Critical Thinking in the Classroom}

Critical thinking is a conversational issue to be intervened in the classroom. Pennycook (1999) maintains that CT is a way to develop questioning attitude in critical approaches and the development of a method of teaching aimed at transformation (p. 314). Lin (1999) capitalizes on teachers' efficiency to teach critical thinking through courses. Whereas, Ruminski and Hanks (1995) believe that teachers should have a clear concept of critical thinking before they embark on teaching and assessment the output. Moreover, Jeong (2003) argues that interaction in the classroom promote CT among students.

Good CT writing helps readers to go through argument so that they do not need to stop to consider where they are in the argument since when they express their opinion and suggestions to solve a problem. I believe that teachers can teach students be critical thinkers by giving them enough opportunity to engage in learning and teaching process not to sit in the class as passive participants. Such skills should be an integral part in school curriculum that has aims in the teaching plan.

Revision teaches students thinking if they are given enough time to revise their essays since writing causes further discovery and development of ideas. Revising drafts promotes CT skills through thought-provoking content since such skills will be developed through synthesizing composition in the classroom (Snow \& Brinton, 1988). Some students find themselves in difficult situation with the reasoning tasks, regardless of their language proficiency. In the writing classroom, teachers can follow some steps to facilitate writing and teach CT. for example, students are asked to describe, compare, gather information, analyze, and argue for or against while they are writing. Writing is a recursive process that guides students to analytical stage during revising the content.

\subsection{Approaches of Incorporating Thinking Skills in the Curriculum}

Many researchers agree that integrating thinking skills in the curriculum will help students enhancing their thinking abilities (Alghafri \& Hairul, 2014). In my opinion, both critical and creative thinking must be inserted in learning and curricula through writing assignments. Cottrel (2005) states that an argument paves the way learn CT during arguing and discussing a problem. From my experience in teaching writing; CT can be developed through argument, compare and contrast, cause and effect patterns since students infer solutions to the problem they are writing about and find 
reasons to come out with ending that persuade readers about an issue. EFL teachers have a room to train students to be critical thinkers by asking them to write, rewrite relevant information as a complete paragraph. The ultimate goal of integrating CT in the classroom is to increase students' competence in thinking which will instigate learners to refute and discuss an idea before accepting it.

In addition, revising process adds more tainting to students to be able to criticize, analyze and evaluate information. Cottrell points out that categorizing skill prepares learners to identify related ideas and helps them to recognize differences and similarities (27). An argument includes a position or a point of view to persuade others to accept that point since writers attempt to persuade readers to a particular point (40). Certain words are used to signal the opening of the argument. These include words such as first, first of all, to begin, first and foremost, at the outset, initially...etc. The line of reasoning is to help readers keep track of the thinking so as to emphasize the message that the writers want to convey to the readers.

Thinking skills should not be taught in isolation, but to be inserted in curriculum. McPeck's (1981) thinks that CT is one kind of thinning that cannot be done in vacuum (49). From my experience, CT can be taught not only in the writing class but also in reading where students can infer information from texts since they are given enough time to interact with texts.

\subsection{The Effect of Teaching Critical Thinking on Education}

Education always improves when teachers use a variety of techniques in the classroom to get positive output. Consequently, education will be developed since teachers use the most modern teaching methods and they are exposed to consistent training. Moreover, education will be improved in general when teachers have updated training and select suitable pedagogy in order to engage students in learning and teaching process. For example, classroom activities such as discussion, dialogue, debating, group work and presentation to prepare students for the actual writing assignments (Cheng, 2004). Ezzedeen (2006) states that U-shaped seating makes pave the way to students to interact and discuss and debate since they are facing each others that grant them enough chance to instigate their schemata. Barnawi (2010) argues that it is not easy to teach CT in traditional classrooms due to the dominance of traditional instructors on students' opinion and ideas. He states that CT teaching style grants students to constitute their intellectual, critical, analytical and expressive abilities (p.195).

\section{Methodology}

The present study was carried out to achieve the above mentioned research questions:

(1) a. Are there any differences between students' performance who draft, redraft and edit their writing and those who do not at BUC?

b- Do BUC students who are exposed to CT improve their writing performance?

(2) a. To what extent do EFL/ESL teachers integrate CT in the writing classes at BUC?

b- What are the factors that affect on using CT in teaching the writing skills at BUC?

\subsection{Participants}

To answer the research questions, 100 female Omani students and 20 EFL teachers (10 females and 10 males). Students are divided into two groups: Control and Experimental group.

\subsection{Instruments}

To obtain measures of the effect of teaching critical thinking on students' writing performance a combination of instruments were used to get an accurate data. Pre and posttests are given to students to assess the progress of treatment group who were exposed to writing assignment using signal words through the stages of Process Writing. Questionnaire questions are administered to EFL teachers who are working at BUC.

\subsection{Treatment Approach}

The researcher of this study tailored a treatment approach that fit to BUC students since they have their special case. For example, they have different socio-economic, traditions, circumstances that affect on their education. Writing Process is used in teaching students CT through writing assignments. First, EXP. Group is trained on using PW approach. They follow up its stages (Brainstorming, drafting, revising and editing then the final product where they use transition words that move the reader smoothly from point to another. The following table summarizes the treatment conducted in experimental group who are exposed to intensive writing focusing on CT skill. Groups and peers worked hard during a semester to achieve massive of written work. The teachers give guidelines and feedback. A collection of essay writing by students in the Exp. class using signal words to insert their opinions in the writing class output. The written assignments are kept in student's portfolios for assessment and following up their progress using CT in writing different types of essays focusing on CT skill to accommodate students accept this philosophy in the BUC writing classroom. Teaching CT style adopted and adapted to Omani students' values, culture, beliefs prior knowledge and experiences they are exposed to before. They are exposed to persuasive, argumentative, comparison/contrast, classification, cause/effect, researched and reaction essays where is focus on $\mathrm{CT}$. 
The chart below demonstrates the treatment approach conducted in the Exp. Class where CT is taught in the writing classroom.

Critical thinking cannot be taught in vacuum

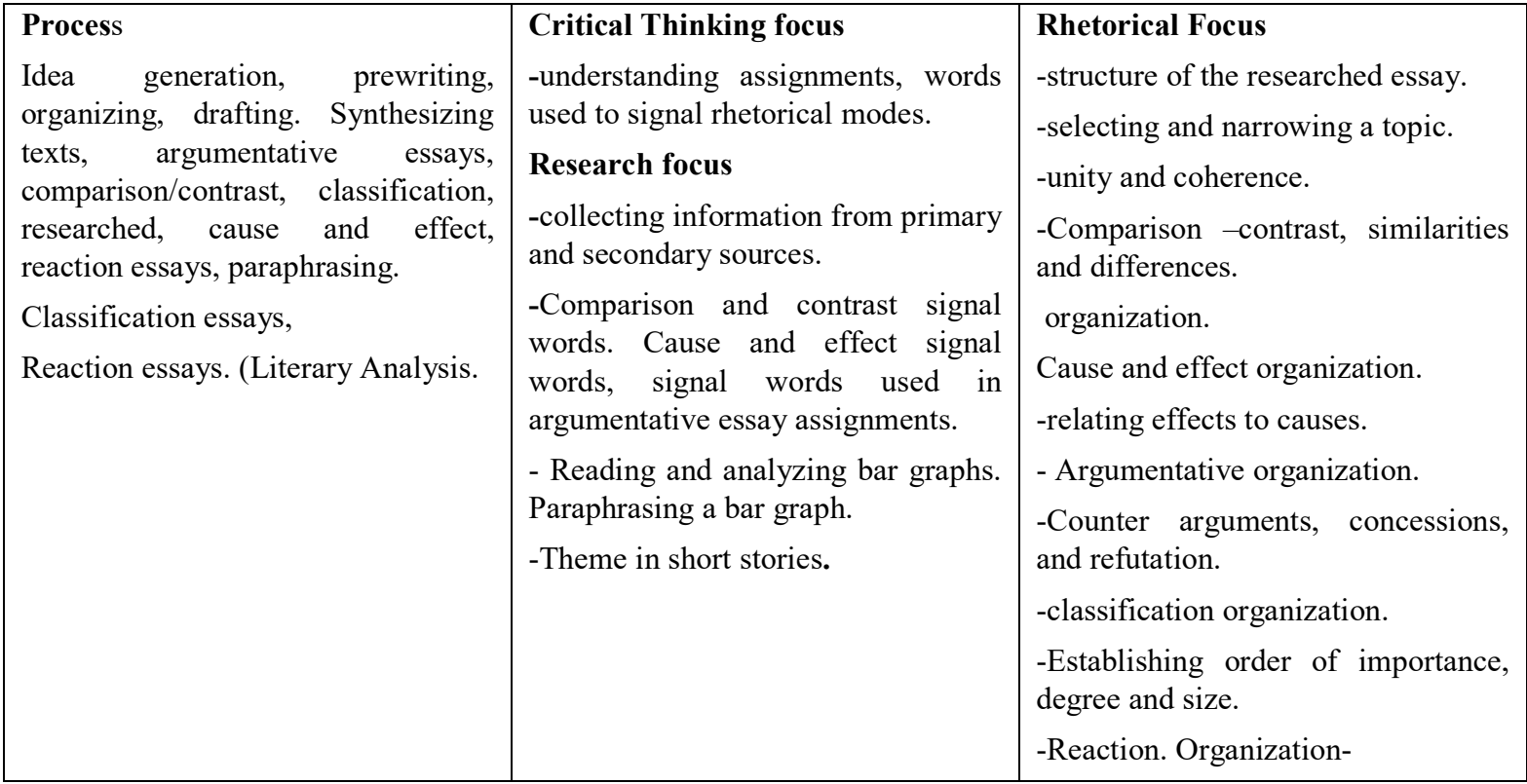

The students in the treatment group are exposed to intensive training on writing using CT signal words through process writing approach in achieving writing assignments. The students are given many writing assignments using process approach and signal words and redraft and revise the products in groups and pairs. Also, teacher's feedback on students' essays guides them to use CT signal words in writing which grants thinking skills during brainstorming, writing, redrafting and revising in which students can go back to their previous experiences they select appropriately.

\section{Results and Discussion}

The findings of this study revealed that effectiveness of CT instruction is influenced by conditions in the instructional environment comprising the instructional variables (teaching strategies and CT instructional approaches), and to some extent by student-related variables (year level and prior academic performance). Moreover, the type of CT measures adopted (standardized vs. non-standardized) appear to influence evaluation of the effectiveness of CT interventions. The findings overall indicated that there is a shift towards embedding CT instruction within academic disciplines, but failed to support effectiveness of particular instructional strategies in fostering acquisition and transfer of CT skills. The main limitation in the current empirical evidence is the lack of systematic design of instructional interventions that are in line with empirically valid instructional design principles.

\subsection{Analysis of Pre and Posttest}

At the end of the treatment procedure using Process Writing to teach students in the Experimental group how to write an essay critically. Students in both groups took a writing test similar to the final exam. Three raters participated in marking the given essays and the average was considered. The analysis of data examines if there is significant difference in the result of pre and posttest. The following table demonstrates the means and standard deviation of these tests.

Table 1. Descriptive of pre-test for Experimental \& Control groups

\begin{tabular}{llllll}
\hline Category & Group & $\mathrm{N}$ & Mean & Std. deviation & Std. Error \\
\hline Pre-test & Control & 50 & 55.90 & 16.415 & 2.321 \\
& Exp. & 50 & 56.80 & 14.045 & 1.986 \\
\hline
\end{tabular}

Table 1 illustrates the results of both tests (pre and posttest) shows no big difference between both groups. This indicates that both groups are homogenous. The score shows that the mean of control group is 55.90 and the means of experimental group is 56.80 and S.D is 14.045 . pre and post test assesses the level of students before the treatment procedure to show if there improvement after treatment. The following table demonstrates t.test of pretest. 
Table 2. t-test results of the pretest

\begin{tabular}{llll}
\hline Test & t. & df. & Sig. (2 tailed) \\
\hline Pre-test & -.295 & 98 & .769 \\
& & & \\
\hline
\end{tabular}

Table 2 shows that t-test of pre-test found that there is no significant difference between both groups with ( $\mathrm{p}>0.05)$. This reveals that control and Exp. Groups have got approximate score in pretest that paves the way to conduct the experiment in the experimental writing class.

Table 3. Descriptive of post-test for Experimental \& Control groups

\begin{tabular}{llllll}
\hline Category & Group & $\mathrm{N}$ & Mean & Std. deviation & Std. Error \\
\hline Post-test & Control & 50 & 52.20 & 14.677 & 2.076 \\
& Exp. & 50 & 78.06 & 11.470 & 1.622 \\
\hline
\end{tabular}

Table 3 illustrates the means and Std. deviation of students' scores. The result shows that there is difference between the scores of control and Experimental group. The means and St. deviation of control group is mean 52.20 and St. deviation is 14.677 that indicate to improvement of students' performance and the attitudes of the students in the experimental group has changed whereas the control group has not been affected by the current teaching approach used at BUC. Table 3 illustrates test of pretest and posttest for both groups.

Table 4. t-test result of the posttest

\begin{tabular}{llll}
\hline Test & t. & df. & Sig. (2 tailed) \\
\hline posttest & -9.816 & 98 & 0.000
\end{tabular}

Table 4 demonstrates the significance of posttest. It shows that there is significance in posttest at $(p<.0 .05)$. This reveals that students in experimental group achieved better scores than their counterparts in the control group. Based on the result, students in the Exp. Group have positive attitudes towards using CT in the writing skills.

Based on the analysis of the results of posttest, there is significant difference between students in the control group and the performance of students in the Exp. group. The significance indicates that Exp. group has improved their writing performance after they are exposed to teaching CT through writing essays.

Table 5. Means and std. Deviation of Teachers attitude towards Teaching Critical Thinking at Al Buraimi University College

\begin{tabular}{llcc}
\hline No. & Variables & Median & $\begin{array}{l}\text { Std. } \\
\text { deviation }\end{array}$ \\
\hline 1 & Critical thinking is neglected in the writing classroom. & .607 \\
2 & Traditional writing classroom focuses on Critical Thinking. & 5 & .821 \\
3 & EFL teachers at BUC do not pay much attention to the idea of CT. & .951 \\
4 & Sts. are unable to think critically. & 4 & .733 \\
5 & Sts. have great difficulty when writing compare and contrast essays & 4 & .571 \\
6 & Sts. are unable to organize ideas logically when writing composition. & 4 & .716 \\
7 & Sts. can analyze ideas when drafting. & 2 & 1.261 \\
8 & EFL teachers train sts. On using CT in the classroom. & 4 & 1.716 \\
9 & EFL teachers ask sts. to use argumentative signal words in writing essays. & 2 & .801 \\
10 & Teachers give guidelines to write persuasive writing. & 2 & .587 \\
11 & Teachers find CT a solution to write perfectly. & 2 & .587 \\
12 & Teachers are the most important factor who teach Sts'. CT & 4 & .616 \\
13 & Teachers encourage sts. to promote their CT and creativity in writing. & 2 & 1.137 \\
14 & Teachers integrate CT in writing classes to evaluate sts' ideas. & 1 & .875 \\
15 & Writing classes focus on CT encourages sts' to use previous experiences. & 4 & .968 \\
\hline
\end{tabular}

The main purpose of this study was to reveal the applicability of CT at BUC and to examine the manifold of relationship between theory and practice in teaching CT using Process writing at BUC;. The majority of EFL teachers 
towards CT have high positive points of views regarding the possibility of teaching CT and its effect on students" writing performance at BUC. As shown in table 4. The responses of teachers indicate that the majority of them have positive attitude towards teaching CT at BUC. Their response explores that students at BUC are not exposed to

As shown in Table 5, the findings indicated that most EFL teachers stated that CT thinking neglected in teaching writing in BUC classroom $(\mathrm{M}=5, \mathrm{SD}=.607)$ teachers also supported that traditional writing classroom did not focus on $\mathrm{CT}(\mathrm{M}=1, \mathrm{SD}=821)$, Also they said that teachers at BUC did not care much about $\mathrm{CT}(\mathrm{M}=2, \mathrm{SD}=.951)$ and Student were not well-trained to think critically $(\mathrm{M}=4, \mathrm{SD}=.733)$. Teachers indicated that students had difficulty when writing compare and contrast $(\mathrm{M}=4, \mathrm{SD}=.571)$ they stated also students were unable to organize ideas logically $(\mathrm{M}=4$, $\mathrm{SD}$ 716) They also believed that EFL teachers trained them on using $C T(M=4, S D=1.716)$ they indicated that teachers asked students to use argumentative signal words $(\mathrm{M}=2, \mathrm{SD}=.801)$ and they stated that teachers supported students when writing persuasive writing $(\mathrm{M}=2, \mathrm{SD}=.587)$. They asserted that $\mathrm{CT}$ is a solution for students to write perfectly $(\mathrm{M}=4, \mathrm{SD} .616)$ and that teachers are the most important factor $(\mathrm{M}, \mathrm{SD}=.616)$. They did expected that teachers encouraged students to promote $\mathrm{CT}$ and creativity $(\mathrm{M}=2$, SD 1.137). Also, teachers did not believe that teacher in writing classes integrated $\mathrm{CT}(\mathrm{M}=1, \mathrm{SD} .875)$ but they contends that writing classes using $\mathrm{CT}$ encouraged students to use previous experiences (Median=4, SD .968).

According to the teachers' response, the majority of teachers are proponents of using CT in teaching writing but they indicated that CT are not experienced before at BUC writing classrooms. They found that using CT affected on students' performance positively.

\section{Implementation of critical thinking in the classroom}

The present study was conducted to be suitable for all levels of education and it includes teaching thinking skills to students in writing classroom since writing process includes many stages which grant all students to use their previous experiences and learn how to criticize, analyze and persuade other people in accepting their ideas. The implementation of using CT in BUC classroom requires change in the mentality of students and teachers as well.

The analysis of data reveals that giving learners choices and integrating CT an integral part in teaching the writing skills gives students their responsibility to look after revising the first draft using CT signal words which instigate the schemata. Such process grants students enough opportunity to enhance their writing skills and write perfectly. Students who were engaged in Exp. class achieved better scores in posttest that affected on their attitudes towards writing essays.

\section{Recommendations and suggestions}

This study examined students' perceptions of the CT and its effect on their writing performance. This study recommends that teachers should give great consideration towards teaching CT in the writing classroom since the findings illustrate that using process approach in teaching the writing skills enhances students CT skill in producing well-organized piece of writing. Organizing group discussions are helpful for students who are reluctant in participation in writing class. Involving students helps in achieving the ultimate goal of writing that improve students' communicative competence and intellectual abilities and CT that is taught in healthy writing classroom (Cole, 2008). Teachers are encouraged to adopt and adapt techniques of teaching critical thinking and creative thinking. Also, teachers' role is to be a patient facilitator, guiding students to integrate CT in teaching not only writing but also reading, listening and speaking so as to train students to be critical thinkers. Moreover, the promotion of teaching CT through writing should be considered a primary issue of instruction at BUC since the shallow and passive learning is ineffective in the classroom whereas CT creates active learning where is student-centered approach is required to be applied to employ CT in teaching and learning process. Besides, CT and creative thinking should be kept in course designers' minds. I suggest that writing topics should address students' interests so as to give them enough opportunity to engage in writing to analyze, evaluate, synthesize, apply, and conceptualize the frame of their ideas. Moreover, EFL teachers should refurbish courses to teach CT so as to produce perfect teaching. CT also should be integrated in literature class, writing classes.

\section{Conclusion}

There is further research to determine on the types of tasks and activities to enhance the ability to draw inferences, evaluate arguments and interpret evidence and to find out how best to integrate critical thinking in school curriculum in the Sultanate of Oman. The positive attitudes towards CT encourages curriculum designers to include CT in teaching writing courses at BUC since it affects students' performance in writing skills and encourages creativity in the output of learning.

The findings of this study suggest that incorporating CT in teaching the writing skills encourages students to be enthusiastic, positive and well-motivated. However, there are indications that they some teachers at BUC do not teach CT within writing and the first draft is considered the final. Also, students lack analytical and intellectual skills since they are neglected in the writing skills. Practice using CT signal words and focusing on revising technique in self, pairs and group are necessary.

It is concluded that teaching students CT through writing classes assists students' to be eligible to advanced university level. Teaching CT increases student and teachers' motivation, and ameliorate student behavior in the classroom. The current study shows that the students who tried CT in writing are willing to be positively receptive to innovation in learning and teaching the writing skills. Teaching CT is a way to foster students to work positively when writing essays, they will find a chance to organize their ideas and express their emotion in writing. In conclusion, I would like to 
conclude this study with a word from my experience in the classroom that CT can be taught through writing if students are given enough time to spend on writing assignment since there is room for development to have graduate critical thinkers. The results of this study encourage educators to encourage students be critical thinkers inside and outside of the classroom since creative and CT be a necessary part in curricula.

\subsection{Further Research}

More research is required to identify and cater for students' needs in the various stages i.e., primary, preparatory, secondary, and university. Research is also throughout the various educational systems in the Arab world. Further researches are needed in the following areas:

- To explore how traditional teachers change their techniques of teaching to integrate CT in the classroom.

- To conduct a research on the effectiveness of active learning on learner's level.

- To explore the effect of CT on students' level in the reading courses.

\section{Sponsoring information}

The Research Council and Al Buraimi University College, the Sultanate of Oman.

\section{References}

Alghafri, A.S \& Hairul. N.B.I. (2014). The Effects of Integrating Creative and Critical Thinking on School Students' Thinking. International Journal of Social Sciences and Humanity, 4(6), (- 518 - 525)

Ezzedeen, S.R. (2008). Facilitating classroom discussions around current and controversial issues: Ten recommendations for teachers. College Teaching, 56(4), 230 -236.

Barnawi, O.Z. (2010). Finding a Place for Critical Thinking and Self-voice in College English as a Foreign Language Writing Classroom. English Language Teaching, 4(2). www.ccsenet.org/elt. (June, 2011).

Bean,J. (1996). Engaging Ideas. San Francisco: Jossey-Bass.

Brookfield, S. (1987). Developing critical thinkers. Milton Keyes: Open University Press.

Cheng, Y. J. (2004). Students' sense of campus community: what it means, and what to do about it. NASPA Journal, 41(2), 216-234.

Cole, D. (2008). Constructive criticism: The role of student-faculty interactions on African American and Hispanic students' educational gains. Journal of College student Development, 49(6), 587-605.

Cottrell, S. (2005). Critical Thinking Skills: Developing Effective Analysis and Argument. New York: Palgrave Macmillan.

Hashemi, M.R. (2012). Does Critical Thinking Enhance EFL Learners' Receptive Skills?. Journal of Language Teaching and Research, 3(1). 172 - 179.

Jeong, A.C. (2003). The sequential analysis of group interaction and critical thinking in online threaded discussions. American Journal of Distance Education, 17(1), 25-43.

Jonson, D.W. et al. (2000). Constructive Controversy. Change, 32(1), (28 - 37)

Johnson, D.W. \& Jonson, R.T. (1995). Structuring academic controversy. In S. Sharan (ed.) Handabook of cooperative learning methods. Westport, Connecticut: Greenwood Press.

Kurfiss, J. G. (1988). Critical Thinking: Theory, Research, Practice, and Possibilities. Washington, D: Educational Resources Information Centre.

Ku, Y. L. K. (2009). Assessing students' critical thinking performance: Urging for measurements using Multi-response format. Thinking Skills and Creativity, 4,70-76.

Lin, A.M.Y. (1999). Doing-English-Lessons in the reproduction or transformation of social worlds? TESOL Quarterly, 33(3), $393-413$.

MacKnight, C.B. (2000). Teaching Critical Thinking through Online Discussions. EDUCAUSE QUARTERLY, 4, 38-41. McPeck, J.E.(1981). Critical Thinking and Education. New York: St Martin's Press.

Mirzaii, M. (2012). The effect of oral conferencing and peer response on Iranian EFL learners' writing achievements. Iranina EFl Journal, 8(3), 285 - 300.

Paul, R. W. (1985). Bloom's taxonomy and critical thinking intervention. Educational Leadership, 42(8): 36-39.

Pennycook, A. (1999). Introduction: Critical approaches to TESOL. TESOL Quarterly, 33: 329 - 348.

Pithers, R. T., \& Soden, R. (2000). Critical thinking in education: A review. Educational Research, 42, $237-249$.

Rumiski, H. J., \& Hanks, W.E. (1995). Critical thinking lacks definition and uniform evaluation criteria. Journalism and Mass Education Educator, 50(3), 4 - 11.

Snow, M. \& Brinton, D. (1988). Content-based language instruction: Investing the effectiveness of the adjunct model. TESOL Quarterly, 25(1), $9-27$. 